Vol 2. No 1. Februari 2018

ISSN 2580-5029

\title{
UTILIZATION OF RICE STRAW, MICRO-ORGANISMS EFFECTIVE AND PROBIOTICS TO REPLACE CHEMICAL FERTILIZERS IN FISHING ENTERPRISES
}

\author{
Ulul Ilmi1 ${ }^{*}$, Affan Bachri² \\ ${ }^{1}$ Lecturer of Electrical Engineering S1 Study Program, Faculty of Engineering, Lamongan \\ Islamic University
}

${ }^{2}$ Head of S1 Study Program, Electrical Engineering, Faculty of Engineering, Lamongan Islamic University Veteran Street No. 53A

*Email : ululilmi78@yahoo.co.id

\begin{abstract}
The purpose of this research is to process rice straw into organic fertilizer so it can be used as food source for fishery business. The method used is the experimental method in the field. The results of research that has been done is processing of rice straw able to produce Nitrate $\left(\mathrm{NO}_{3}\right)$ and zooplankton as a source of organic material that serves as a source of food for fish so that rice straw can serve as a substitute for chemical fertilizer in the fishery business area. By using organic materials, then the fishery business results are more hygienic for consumption and can improve the fishery business.
\end{abstract}

Keywords: Rice Straw, microorganisms, probiotics

\begin{abstract}
ABSTRAK
Tujuan dari penelitian ini adalah untuk mengolah jerami padi menjadi pupuk organik sehingga bisa dijadikan sumber pakan bagi usaha perikanan. Metode yang digunakan adalah metode eksperimen di lapangan. Hasil penelitian yang telah dilakukan adalah pengolahan jerami padi yang mampu menghasilkan nitrat (NO3) dan zooplankton sebagai sumber bahan organik yang berfungsi sebagai sumber makanan bagi ikan sehingga jerami padi dapat berfungsi sebagai pengganti pupuk kimia di kawasan usaha perikanan. Dengan menggunakan bahan organik, maka hasil usaha perikanan lebih higienis untuk dikonsumsi dan dapat meningkatkan usaha perikanan
\end{abstract}

Kata kunci: Jerami padi, mikroorganisme, probiotik.

\section{PRELIMINARY}

Since the New Order era, our farmers have been accustomed to using chemical fertilizers. According to farmers, chemical fertilizers are considered as heroes and gods in the world of fisheries. However, if observed more closely, chemical fertilizer is basically only as a 
catalyst only. This means that chemical fertilizer serves to accelerate the reaction so that fish can grow better and bigger. In the beginning it is like that, but along with the development of time, it turns out, due to the chemical fertilizer the growth of fish grows slower and tends to decrease. Besides, the use of chemical fertilizers also have an impact and potentially increasing the cost of fishery business. Starting from this problem, then in this research offered alternative solution through the use of straw, effective microorganisms and probiotics as a substitute for chemical fertilizers. The content of rice straw is lignin (21,40\%), Pentosa (16,94\%), cellulose (34,34\%), nitrogen $(24,70 \%)$, silica (16,98\%), oxygen (33 , 64\%), carbohydrates $(33.71 \%)$, protein $(3.03 \%)$, fiber $(35.68 \%)$, water $(9.02 \%)$, fat $(1.18 \%)$, carbon $(1.33 \%)$ and hydrogen $(1.54 \%)$.

While the effective microorganism has the ability of the first is suppressing the growth of soil pathogens. Understanding the pathogen is to reduce the proliferation of all the harmful bacteria for fisheries business. The second ability is to accelerate the fermentation of waste and organic waste. For the third ability is to increase the availability of nutrients and organic compounds in plants. The fourth ability is to increase the activity of beneficial inducible microorganisms such as Mycorhiza, Rgizobium, solvent bacteria. The fifth ability is to reduce and further the needs of chemical fertilizers and pesticides. While probiotics serve to decompose the toxic gas $\mathrm{H}_{2} \mathrm{~S}$. In addition probiotics also serves to eliminate contamination due to accumulation of organic materials in the base and in the environment of fisheries and to grow beneficial bacteria. Probiotics also serve to accelerate the growth of fish and can protect fish against fish pest attack.

\section{RESEARCH METHODS}

This research is a type of experimental research because in this study conducted experiments on the manufacture of organic fertilizer, with raw materials from rice straw mixed with effective microorganisms and probiotics so as to bring benefits to improve soil conditions and improve the productivity of fisheries.

\section{RESULTS AND DISCUSSION}

Based on the results in the field, data on yields before the application of straw, effective microorganisms and probiotics are shown in the following table.

Table 1 Results of Crop Farm using inorganic fertilizer (urea and TSP 36) on 1 hectare land

\begin{tabular}{cccccc}
\hline No & $\begin{array}{c}\text { Type of } \\
\text { commodity }\end{array}$ & $\begin{array}{c}\text { Number of seeds } \\
\text { sown (tail) }\end{array}$ & $\begin{array}{c}\text { Crop } \\
\text { (kg) }\end{array}$ & $\begin{array}{c}\text { Selling price } \\
\text { (Rp) / kg }\end{array}$ & Description \\
\hline 1 & Vanamie & 5000 & 200 & 55.000 & Harvest time 60 days after \\
2 & Milkfish & 5000 & 100 & 40,000 & ingestion of seedlings \\
3 & Nila & 5000 & 75 & 30,000 &
\end{tabular}

Source : data is processed 2017 
From table 1, it can be seen that the harvest produced by vanamie shrimp is 200 kilo grams, while the milkfish harvest is 100 kilograms and the tilapia yield is 75 kilograms if using inorganic fertilizer.

Table 2 Results of Pond Harvest by using organic fertilizer made of straw, effective micro organisms and probiotics on a land area of 1 hectare

\begin{tabular}{cccccc}
\hline No & $\begin{array}{c}\text { Type of } \\
\text { commodity }\end{array}$ & $\begin{array}{c}\text { Number of seeds } \\
\text { sown (tail) }\end{array}$ & $\begin{array}{c}\text { Crop } \\
\text { (kg) }\end{array}$ & $\begin{array}{c}\text { Selling price } \\
\text { (Rp) / kg }\end{array}$ & Description \\
\hline 1 & vanamie & 5000 & 300 & 55.000 & Harvest time 60 days after \\
2 & Milkfish & 5000 & 200 & 40,000 & ingestion of seedlings \\
3 & Nila & 5000 & 150 & 30,000 & \\
\hline
\end{tabular}

Source : data is processed 2017

From table 2, it can be seen that the harvest produced by vanamie shrimp is 300 kilo grams, while the milkfish harvest is 200 kilograms and the indigo yield is 150 kilograms if using organic fertilizer from straw, effective micro organisms and probiotics.

With these results it can be concluded the use of organic fertilizers made from straw, effective micro-organisms and probiotics can improve the results of fisheries.

Rice Straw contains water or $\mathrm{H}_{2} \mathrm{O}$. With the content of $\mathrm{H}_{2} \mathrm{O}$ hay can be used as material for photosynthesis process. so it can produce the much needed oxygen to support the growth and life of the fish. Rice Straw is an agricultural waste that has the potential to be processed into chemical fertilizer substitute by fermentation process by using probiotics and effective microorganisms. The rice straw that undergoes the fermentation process eventually turns into a zooplankton.
Zooplankton is an indispensable microorganism for fish food ingredients.

With this fermentation process, the ability of straw to provide zooplankton as a result of the process of photosynthesis, is very important needed to support the growth of fish. Thus straw is a very important material needed as an alternative material to support the fishery business as well as replace the position of chemical fertilizers in fishery business because it has the content of $\mathrm{H}_{2} \mathrm{O}$ and has the ability to produce zooplankton. Straw becomes an altrenative material to support the fishery business, because the condition of land used for fishery business is often exposed to chemicals sourced from chemical fertilizers.

In addition to the content of $\mathrm{H}_{2} \mathrm{O}$ contained in organic fertilizers made from straw-based materials, effective microorganisms and probiotics, there are also other substances. Other substances, the first concerning salinity content. In this organic fertilizer salinity content of 12 parts per 
trilliun (ppt). This is significant in $1 \mathrm{~kg}$ of organic fertilizer contained salinity level of $12 \times 10^{-3}$ milligrams.

The other substance content, the second is $\mathrm{PH}$ amount 5. This content is significant in this organic fertilizer there is a $\mathrm{PH}$ value of 5 . The other substance content, the third is the temperature of probioticeffective microorganisms in organic fertilizer of 32 degrees celsius.

Temperature of 32 degrees Celsius indicates the temperature in this organic fertilizer is warm, indicating there is activity of micro organisms in this made organic fertilizer. Other substances, the fourth is a nitrate compound of 140 milligrams / liter. This means that the content of nitrate compounds in every kilogram of organic fertilizer is 140 milligrams. In the presence of nitrate compound content of 140 milligrams, in every kilogram of organic fertilizer can dissolve nitrate compound of 140 milligrams. The greater the number resulting from the content of nitrate compounds in organic fertilizers, the greater the solubility resulting from the content of nitrate compounds in organic fertilizers.

With the presence of several substances contained in organic fertilizer made from rice straw, the potential of straw is very good to be used as a raw material for the manufacture of organic fertilizer as a substitute for chemical fertilizers in fishery business. With these results, it can be concluded that straw, effective microorganisms and probiotics can be used as raw materials for the manufacture of organic fertilizers in liquid form which serves to replace chemical fertilizer position in fishery business.

The use of liquid organic fertilizer causes water in ponds to be cleaner and very suitable for fish growth. In addition, the use of liquid organic fertilizer can change the waste that is submerged in ponds into food for fish. Through the use of liquid organic fertilizers, the remnants of feed and organic matter are lifted to the surface of the water into fish feed ingredients. Liquid organic fertilizer can also improve the quality of fishery water through oxidation process in fishery waters so that it can reduce the material that is toxic (toxin).

\section{LITERATURE}

Djuarnani,dkk, 2005. Cara cepat membuat kompos. Agromedia Pustaka. Jakarta Selatan

Harianto, Bagus, 2007. Cara praktis membuat kompos. Agromedia. Jakarta Selatan.

Haumahu. 2012. Pengaruh Effective Inoculant Promi dan Em4 terhadap LajuDekomposisi dan Kualitas Kompos dari Sampah Kota Ambon. Agrologia Journal. Vol.1/NO.2. Ambon.

Hepher, B. 1988. Nutrion of Pond Fish. Cambridge University Press. Canbridge.

Irianto, A.2003.Probiotik Akuakultur.Gajah Mada University Press.Yogyakarta. 
Kordi, 1996. Parameter Kualitas Air. PT. Rineka Cipta. Jakarta.

Mudjiman. 1998. Makanan Ikan. PT. Penebar swadaya. Jakarta.

Mulki. 2005. Pemilihan Teknologi Tepung Ikan. Mimbar ilmiah No. 2/15/2005.

Murbandono, 2000.Membuat kompos. Penebar Swadaya. Jakarta

Murtidjo. B. 2001. Beberapa Metode Pengolahan Tepung Ikan. Kanisius. Yogyakarta.

NRC (National Research Counsil). 1983. Nutrient Requirement of Warmwater fishes and shellfishes. National Academy of Science, Washington D.C.

Prahasta, A. dan Hasanawi Masturi. 2009. Agribisnis Udang Windu. Pustaka Gravika. Bandung.

Puspita, Ati. 2005. Jenis Dan Kualitas Tepung Ikan. Buletin Teknik Litkayasa Akuakultur Vol. 4 No. 1 Tahun 2005.
Soetomo, M. 1990. Teknik Budidaya Udang Windu. Sinar Baru. Bandung.

Suyanto, R.A. dan Ahmad Mujiman. 2005. Budidaya Udang Windu. Penebar Swadaya. Jakarta.

Tanpa Pengarang, 2017. Inilah Beberapa Kandungan Bahan Organik Jerami Padi,http://budidayatanamanhias.xyz ¿inilah-beberapa-kandungan-bahanorganik-jerami-padi/. akses 5-112017

Yousefian, M. \& M. S. Amiri. 2009. A Review of the Use of Prebiotik in aquaculture for fish and shrimp. African journal of Biotecnology Vol.8 (25), pp.7313-7318.

Zizhong, Q., Z. Xiao-Hua, N Boon and P. Bossier, 2009. Probiotics in aquaculture of China-Current State, Problem sand Prospect. Aquaculture 290: 15-21 